\title{
La igualtat d'oportunitats a la universitat: les percepcions del PDI
}

\author{
Inma Pastor Gosálbez* \\ Àngel Belzunegui Eraso* \\ Blanca Moreno Triguero* \\ Carmen Mañas Rodríguez** \\ *Universitat Rovira i Virgili. Facultat de Ciències Jurídiques \\ ${ }^{* *}$ Universitat Rovira i Virgili. Unitat de Sociologia \\ inma.pastor@urv.cat \\ angel.belzunegui@urv.cat \\ blanca.moreno@urv.cat \\ carmen.manas@urv.cat
}

Recibido: 28-03-2007

Aceptado: 12-03-2009

\section{Resum}

Larticle que presentem facilita els resultats principals de la recerca La igualtat d'oportunitats per raó de gènere a la Universitat Rovira $i$ Virgili. Concretament, aquells que fan referència a l'anàlisi de les percepcions de gènere del collectiu del personal docent investigador en igualtat d'oportunitats, mitjançant les dades obtingudes dels índexs de funcionament paritari, d'igualtat formal, de sensibilització en gènere i el general de percepció de gènere, que aglutina els anteriors i que proporciona el posicionament dels col-lectius femení i masculí sobre el conjunt de mesures proposades d'acció positiva i de transversalitat. Seguidament, hem abordat la presència de la temàtica de gènere en els plans d'estudi.

Paraules clau: gènere, igualtat, organització.

Resumen. La igualdad de oportunidades en la universidad: las percepciones del PDI

El artículo que presentamos facilita los principales resultados de la investigación La igualdad de oportunidades por razón de género en la Universidad Rovira $i$ Virgili. Concretamente, aquellos que hacen referencia al análisis de las percepciones de género del colectivo del personal docente investigador en igualdad de oportunidades, mediante los datos obtenidos de los índices de funcionamiento paritario, de igualdad formal, de sensibilización de género y el general de percepción de género, que aglutina a los anteriores y proporciona el posicionamiento de los colectivos femenino y masculino sobre el conjunto de medidas propuestas de acción positiva y de transversalidad. Seguidamente, hemos abordado la presencia de la temática de género en los planes de estudio.

Palabras clave: género, igualdad, organización.

Abstract. The Equality of Opportunities at the University: the Perceptions of the Teaching and Research Staff

The following article provides the main results of the research project Equality of opportunities related to gender at the University Rovira $i$ Virgili. Especifically, it analyzes an analysis 
of the gender-related perceptions of equal opportunities by the Teaching and Research Staff based on data from the following indexes: Joint Functioning, Formal Equality, Gender Sensitizing, and General Gender Perception which agglutinates the previous ones and provides the positioning of feminine and masculine groups with respect to the set of proposed instruments or measures of positive action and mainstreaming. Finally, we have examined the presence of gender-related subjects within the degree program at the University.

Key words: gender, equality, organization.

\section{Sumari}

1. Introducció $\quad 5$. Gènere i transversalitat en la docència

2. Plantejament de l'estudi sobre igualtat

6. Conclusions

3. Antecedents teòrics i normatius

7. Fonts bibliogràfiques

4. Trajectòries acadèmiques del PDI i percepcions sobre el gènere a la Universitat

\section{Introducció}

Durant els darrers trenta anys, les dones espanyoles han protagonitzat un gran avenç social, però, malgrat la supressió de les discriminacions formals en el règim jurídic, no han assolit encara un grau suficient de presència en esferes de la societat, en especial en els càrrecs de comandament i de poder. Aquesta situació no reflecteix l'evolució cap a la igualtat real i efectiva dels drets entre els homes i les dones. En altres paraules, en la realitat actual hi ha una clara dissociació entre les idees d'igualtat i democràcia i les pràctiques finals resultants.

Les tradicionals desigualtats entre els treballs dels homes i els de les dones no han desaparegut totalment, sinó que han experimentat un procés de transformació. L'increment de la presència femenina al mercat laboral, així com els avenços en l'escolarització de les dones, marquen un punt d'inflexió en la història recent de les relacions entre els dos sexes. Tanmateix, aquesta transformació és un procés amb avenços i retrocessos. Com apunten Maruani, Rogerat i Torns (2000), els progressos es mesuren en termes de llibertat i autonomia, però també hi ha retrocessos i estancament que, en el context de l'àmbit laboral, s'anomenen sobrequalificació, subocupació, segmentació i segregació. La participació desigual i discriminatòria dels homes i les dones en el mercat de treball, i la també desigual assumpció de responsabilitats envers les càrregues familiars, han estat darrerament estudiades per part de diverses especialistes i des de diverses perspectives (Sensat, Varella, 1998; Gómez Bueno, 2001). Les conclusions més destacables mostren, d'una banda, que hi ha més homes actius i ocupats que no pas dones, i més dones que no pas homes a l'atur. D'altra banda, s'hi constata que, entre les dones que estan ocupades, hi ha una important segregació tant horitzontal com vertical, és a dir, les dones estan concentrades en 
algunes branques d'activitat i en els llocs de menys categoria professional. Aquest és un fet directament relacionat amb l'assumpció, per part d'elles, de la majoria de responsabilitats que genera la vida familiar, és a dir, la «funció reproductora», que presenta tres dimensions, que són, de forma succinta, l'estrictament biològica, la derivada de la dimensió social i cultural i la relacionada amb les tasques de cura, gestió i manteniment de la força de treball, passada, present i futura (Carrasquer et al., 1998). En altres paraules, la "doble presència», que expressa la doble càrrega $\mathrm{i}$ intensitat del treball — productiu i reproductiuviscuda de forma sincrònica en un mateix espai i temps (Balbo, 1978).

A Datos y cifras del sistema universitario (MEC, 2005 ${ }^{1}$ ), s'hi mostra que les aules universitàries s'han feminitzat a Espanya: les dones suposen el $54 \%$ de les matrícules en alguna de les titulacions durant el curs 2004-2005. En canvi, entre el professorat universitari, les dones representen només el 33,1\%, percentatge que es redueix al $13 \%$ en el cas de les catedràtiques. Aquesta xifra ha variat poc en els darrers deu anys. En el curs 1993-1994, el percentatge de dones entre el professorat universitari era del 31,09\%. Observem, doncs, mitjançant aquestes xifres, el sostre de vidre que existeix en el personal docent $\mathrm{i}$ investigador (PDI) femení. Les dones constitueixen més de la meitat de la població estudiant de llicenciatura i el 55\% de graduades a la Unió Europea (UE), presència que no es reflecteix en els nivells superiors de la carrera científica. Els comitès de política científica, en la distribució de recursos, en la concessió de beques, com a membres d'acadèmies i dirigents de col-legis professionals, estan integrats per científics que pertanyen al nivell superior, i és, precisament, en aquestes instàncies on hi ha un dèficit més gran de presència femenina.

En aquest article, s'hi presenta una selecció de resultats d'un estudi més ampli elaborat l'any 2006 titulat La igualtat d'oportunitats per raó de gènere a la Universitat Rovira $i$ Virgili, que neix en sintonia amb les polítiques adoptades des de la UE en matèria de gènere i s'avança en el temps a la Llei de la igualtat (BOE, 23/03/2007), aprovada per les Corts espanyoles el dia 15 de març de 2007.

L'estudi consta de diverses parts. La primera analitza, de forma descriptiva, mitjançant les dades facilitades pel Departament de Recursos Humans de la URV, la situació dels tres col-lectius que formen la comunitat universitària: el personal docent investigador (PDI), el personal administratiu i de serveis (PAS) i l'alumnat. Seguidament, es va revisar el marc normatiu i legal de les polítiques principals en matèria d'igualtat d'oportunitats vigents actualment. En tercer lloc, es va elaborar un qüestionari per conèixer, entre altres, les percepcions que hi ha sobre les desigualtats de gènere a la URV i la consciència que en tenen els col-lectius de PDI i PAS. Per finalitzar, es va realitzar una anàlisi de la presència de la temàtica de gènere en els plans d'estudi de la Universitat a partir del disseny dels plans d'estudi de diferents titulacions.

El nostre article presenta un recull de dades $\mathrm{i}$ interpretacions centrades en les dues darreres parts de l'estudi. A saber, d'una banda, en l'anàlisi de les per- 
cepcions de gènere del col-lectiu PDI en igualtat d'oportunitats i, d'altra banda, en la presència de la temàtica de gènere en els plans d'estudi.

\section{Plantejament de l'estudi sobre igualtat}

En el context europeu actual, la URV està realitzant un important esforç per tal d'aplicar els criteris que es deriven de la Declaració de Bolonya, de juny de 1999. És a dir, l'adopció d'un sistema comparable de titulacions universitàries i la promoció de la qualitat i de l'excel-lència com a valors indestriables de l'educació superior europea. En aquesta modificació de l'espai universitari europeu, és necessari que la transversalització de gènere hi sigui present, a fi de transformar les organitzacions en espais més igualitaris, és a dir, que es produeixi una reformulació de les posicions i de l'accés a la presa de decisions i l'assumpció de polítiques que possibilitin mesures concretes per conciliar la vida professional, personal i familiar dels col-lectius que engloben la Universitat. Tots aquests criteris estan en plena sintonia amb les directrius europees actuals.

El plantejament metodològic multimètode, és a dir, la combinació de tècniques qualitatives i quantitatives, va derivar en l'anàlisi de dades dels registres de la URV $i$ en la recollida de dades primàries a través d'enquestes, que es completà amb la recerca i la revisió documental i bibliogràfica. Les dades dels registres van permetre obtenir una radiografia descriptiva de quina era la situació laboral a la URV, tot comparant el col-lectiu de dones i el d'homes. Amb la informació de l'enquesta, es va copsar la percepció del col-lectiu PDI en relació amb les trajectòries professionals $\mathrm{i}$ amb els possibles determinants d'aquestes. L'objectiu que es perseguia amb la utilització d'aquestes eines metodològiques era fer una radiografia i captar la interpretació que els subjectes fan de les seves carreres professionals. De forma paral.lela, va interessar conèixer quin és el tractament curricular que, en aquests moments, es fa de la problemàtica de la desigualtat per gènere.

\section{Antecedents teòrics i normatius}

Atès que la URV és una institució pública que ha de donar resposta a objectius i necessitats socials definides en un context d'interacció democràtica, es considera necessària la revisió de les propostes polítiques i la definició de principis i objectius que unes altres instàncies polítiques estan dissenyant envers les desigualtats existents per raó de gènere. Ens referim a les polítiques europees, estatals i nacionals que s'han anat configurant al voltant d'aquesta problemàtica. Prèviament, ressenyem alguns estudis marc que han destacat per les seves aportacions en el camp de la igualtat d'oportunitats.

Tal com se subratlla a She figures ${ }^{2}$ : «perquè l'Àrea Europea d'Investigació tingui èxit, és encara d'importància suprema que les dones continuïn aug-

2. European Commission (2003), "Women and Science», She figures, women and science, statistics and indicators. Science and Society, unitat 5. [http://europa.eu.int/comm/research/ science-society/women-science/women-science_en.html] 
mentant la seva participació en la ciència. Les seves veus s'han de fer escoltar com a decisions en la ciència i com a catalitzadores del canvi en el lloc del treball científic. La ciència ha de quedar lliure de les tendències d'un sol gènere».

Aquesta recerca se suma a l'esforç de diferents organismes públics i privats, estatals i europeus, els quals han desenvolupat recerques i informes sobre la situació de la dona al món laboral i, en especial, en el món acadèmic i de les ciències, sense excloure'n les repercussions socials i de tota índole que esdevenen de les conclusions que se'n poden treure. En destaquem, per la seva contemporaneïtat, els textos següents: a) Informe de Politica Científica de la Unión Europea: Promover la excelencia mediante la integración de la igualdad entre géneros, estudi desenvolupat per l'informe del grup de treball ETAN (European Technology Assessment Network on Women and Science), sobre les dones i la ciència, de la Direcció General d'Investigació de la Comissió Europea, 2001; b) She figures, women and science, statistics and indicators, elaborat per la UE, l'any 2003, que, com anuncien, la seva metodologia, estadístiques i conclusions han de constituir un instrument sòlid per a investigadors, polítics i directors de recursos humans, i c) International gender, science and technology information, estudi de C. Wenneras i A. Wold, del Massachusetts Institute of Technology ${ }^{3}$, el qual conclou que l'èxit a la universitat per part de les dones ja no pot ser explicat per la manca de productivitat científica o acadèmica. Amb igualtat de mèrits, el lloc de treball que s'obté és més baix i el temps mitjà que es triga a superar un nivell determinat és sempre superior al dels homes.

En segon lloc, s'emmarca en la línia que han obert a Espanya dues institucions que han avaluat internament la situació dels homes i de les dones: $a$ ) Des del CSIC, la publicació dels informes Mujeres investigadoras del CSIC sobre la presència i la participació femenina a diferents nivells, que van derivar posteriorment en La posición y producción de las investigadoras del CSIC en Catalunya. Informe interno, realitzat per la Comisión Mujeres y Ciencia del $\mathrm{CSIC}^{5}$; b) El sexisme a la Universitat Autònoma de Barcelona: Propostes d'actuació $i$ dades per a un diagnòstic, coordinat per la Dra. Izquierdo, del Departament de Sociologia de la mateixa universitat, l'any 2004. Estudi que ha influenciat decisivament la posada en marxa de l'Observatori per a la Igualtat i s'ha utilitzat com a treball previ per a la redacció del Pla d'Igualtat de la citada universitat.

Les polítiques públiques d'igualtat d'oportunitats han tingut i tenen com a objectiu central possibilitar l'accés de les dones a l'espai públic. Nogensmenys, encara que s'hagin aplicat al nostre país impulsades des de la UE, la desigualtat no ha desaparegut. Les dones espanyoles i catalanes s'han incorporat tardanament al treball productiu remunerat, en comparació amb les seves homòlogues europees. Ho han fet en determinats espais productius, i encara, a

3. Pàgina web: www.wigsat.org/GSTPMap.html

4. Mujeres investigadoras del CSIC. Subdirección General de Recursos Humanos del CSIC, 2001.

5. Comisión Mujeres y Ciencia del CSIC, febrer de 2004. 
l'actualitat, n'hi ha absències en algunes categories superiors professionals i de prestigi social. La raó explicativa principal recau en el fet que l'accés al món del treball no ha modificat substancialment la càrrega de responsabilitats a l'esfera domèstica reproductiva. Tal com assenyala Astelarra $(2005)^{6}$, la societat ha creat institucions i mecanismes que, en conjunt, formen el sistema social de gènere, mitjançant el qual s'obté la primera explicació sobre la dualitat social en femení i en masculí. Lorganització social de gènere segueix adoptant la forma de divisió sexual del treball: l'assignació de l'espai privat a les dones i de l'espai públic als homes. Aquesta fórmula és vigent encara, atès que la incorporació de la dona a l'esfera pública està fortament condicionada a la seva permanència a l'esfera privada, a la «doble presència», tot i que el model de família male breadwinner ${ }^{7}$ està perdent força com a pauta de referència.

Les estratègies polítiques per fer minvar la desigualtat de partida són: la igualtat d'oportunitats, les polítiques d'acció positiva i la transversalització de gènere (mainstreaming). Per l'evolució històrica de la transició democràtica a Espanya, la incorporació a l'agenda política de la no-discriminació arribà quan molts altres països europeus ja havien desenvolupat polítiques d'acció positiva (Astelarra, 2005). Al nostre país, formalment i davant la llei, no hi ha cap discriminació ni desigualtat per raó de gènere, en cap àmbit d'actuació. A la universitat, com a institució d'educació superior pública, hi ha una igualtat formal reconeguda. Malgrat això, aquesta igualtat formal no és garantia d'igualtat real, i és amb la voluntat d'analitzar aquesta disjuntiva que considerem necessari fer una anàlisi dels processos de desigualtat al si de la pròpia institució universitària.

En resum, en les últimes dues dècades, han estat moltes les polítiques públiques impulsades i desenvolupades des de la UE i des d'Espanya, seguint l'estratègia política en els tres àmbits d'actuació: la igualtat d'oportunitats, l'acció positiva i la transversalització. El conjunt de mesures desplegades, i més en el marc actual de la Llei d'igualtat entre homes i dones (2007), pot conduir a canvis en el sistema social de gènere, i pot contribuir a generar condicions més favorables per a l'accés de les dones a l'espai públic, la qual cosa eleva a rang normatiu l'equilibri representatiu dels homes i de les dones en òrgans i nivells de poder i corregeix les desigualtats formals. Paral-lelament, es tracta d'avançar en la identificació dels factors que encara dificulten l'assumpció de responsabilitats públiques per part de les dones i de garantir la igualtat d'oportunitats. De forma complementària, s'han de tenir en compte també les polítiques d'acció positiva i el treball des d'una òptica de la transversalització de gènere en totes les propostes, accions i estratègies que desenvolupi una universitat pública, representant del progrés educatiu, cultural i social, tal com la pròpia URV recull en l'article quart del seu Estatut: «la Universitat es regeix pels principis d'autonomia, llibertat, democràcia, justícia, igualtat i no-discriminació, inde-

6. Judit Astelarra (2005), Veinte años de políticas de igualdad, Madrid, Cátedra.

7. El model male breadwinner es basa en la definició de l'home "cap de família» i la dona «mestressa de casa». 
pendència i pluralitat. La comunitat universitària, i en especial els òrgans de govern de la Universitat, han de donar plena efectivitat a aquests principis». Ho complementa, així mateix, amb l'article cinquè, apartat $b$ : «la Universitat ha d'afavorir el pensament crític, la cultura de la llibertat i el pluralisme, i la transmissió dels valors propis d'una societat democràtica, oberta i solidària».

\section{Trajectòries acadèmiques del PDI i percepcions sobre el gènere a la Universitat}

La major part de les dones que integren la comunitat de la URV han estat contractades en els darrers anys. Això explica, en part, que el col-lectiu femení del PDI sigui una plantilla jove i feminitzada, però amb segregació vertical favorable als homes, a nivell d'ingressos. Segons dades de febrer de 2006, les dones del col-lectiu PDI representen el 41,7\%, mentre que el 58,3\% són homes, d'un total de 1.618 membres.

Tal com s'observa a la taula 1 , s'ha produït un augment de presència femenina com a docents a la URV des de 1998 fins a l'actualitat. Tanmateix, la presència de dones docents en les categories acadèmiques més elevades encara està molt per sota de la presència masculina, tal com es pot observar al gràfic 1 .

Veient aquest indicador de la presència de les dones i dels homes en les categories acadèmiques, ens preguntem per aquestes diferències i si la seva

Tabla 1. Personal docent i investigador segons sexe. Anys 2006 i 1998

\begin{tabular}{lccc}
\hline Sexe & \multicolumn{2}{c}{2006} & $\mathbf{1 9 9 8}$ \\
\hline Home & $58,3 \%$ & $(943)$ & $63,5 \%(529)$ \\
Dona & $41,7 \%$ & $(675)$ & $36,4 \%(303)$ \\
Total & $100 \%$ & $(1.618)$ & $100 \%(832)$ \\
\hline
\end{tabular}

Font: elaboració pròpia.

Gràfic 1. Composició del PDI per categories laborals en percentatge

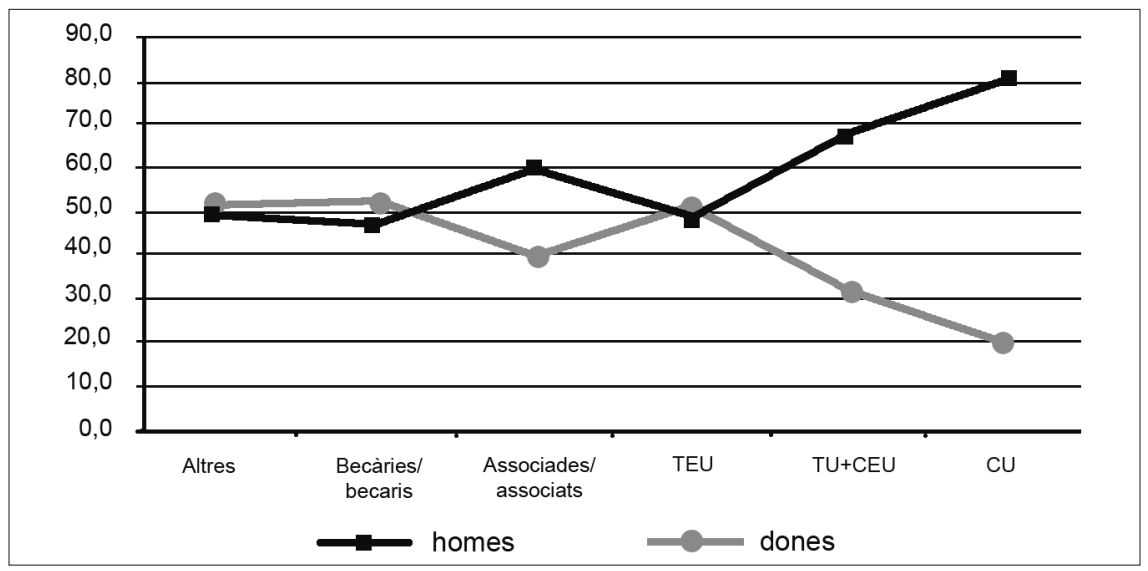


naturalesa té a veure amb qüestions distintives des del punt de vista curricular, amb factors organitzatius (com ara, per exemple, la presència de dones en els llocs de presa de decisions) i amb la càrrega domèstica més elevada que suporten les dones. En tot cas, podem avançar que la discriminació femenina a la Universitat se sustenta en mecanismes subtils i poc explícits, que en dificulten la identificació.

L'elaboració d'un qüestionari ha permès conèixer la posició i les percepcions del col-lectiu PDI davant la igualtat d'oportunitats a la URV. A més a més d'una sèrie de dades sociodemogràfiques i de trajectòria professional i acadèmica del PDI, el qüestionari contenia diverses bateries de preguntes per conèixer la percepció del PDI sobre diversos aspectes relacionats amb la situació de les dones i dels homes a la Universitat, així com també si hi havia percepcions diferenciades entre el col-lectiu femení i el masculí del professorat en relació amb mesures concretes per corregir les desigualtats. El nombre de respostes obtingudes a través del qüestionari enviat a tot el PDI va ser, finalment, de 336, una vegada desestimats alguns qüestionaris. Aquest nivell de respostes facilita que els resultats tinguin un abast limitat pel que respecta a les generalitzacions a tot el PDI de la URV. Per tant, la informació que es detalla a continuació fa referència exclusivament al professorat que ha contestat el qüestionari i té el valor d'assenyalar percepcions i tendències a l'hora de situar les qüestions que s'hi tracten. Malgrat això, s'ha considerat necessari realitzar tests no paramètrics per a determinats resultats, amb la finalitat d'observar si existeixen o no diferències estadísticament significatives i no fruit de l'atzar.

Sobre la població enquestada, d'acord amb les dades facilitades per Recursos Humans de la URV, la composició del PDI segons sexe és la següent: un 41,7\% són dones i un 58,3\%, homes. Aquesta proporció ha quedat alterada en les respostes de l'enquesta dirigida al PDI, de manera que s'ha obtingut un 51\% de respostes per part d'homes i un $49 \%$ de dones. Hi ha, per tant, una petita sobrerepresentació femenina en la participació de l'enquesta, fet que no invalida la informació obtinguda i que posa de manifest, des del nostre punt de vista, una motivació més gran del col-lectiu femení del PDI de la Universitat per respondre el qüestionari. Respecte a la distribució per edats del PDI que ha contestat l'enquesta, un 16\% té menys de 31 anys, un $40 \%$ té entre 31 i 40 anys (és el grup en què es té descendència) i un $44 \%$ té més de 40 anys. També aquí hi ha diferències respecte a la distribució per edats segons les dades de Recursos Humans. Han contestat més el PDI dels grups d'edat més joves (fins als 30 anys i entre 31 i 40 anys, especialment aquests últims) i, per sota de la seva presència real, el col-lectiu de més de 40 anys. Observem a continuació la taula resum següent, on s'han recollit les trajectòries professionals de forma diferenciada entre homes i dones:

El PDI ajudant, becari i associat. El 58,6\% dels homes que, en el moment d'ingressar a la Universitat, pertanyen a aquesta categoria, han ascendit a les superiors, mentre que entre les dones s'ha produït un ascens del 61\%. Referent a aquesta categoria d'ingrés, com ens mostren les dades, hi ha un petit per- 


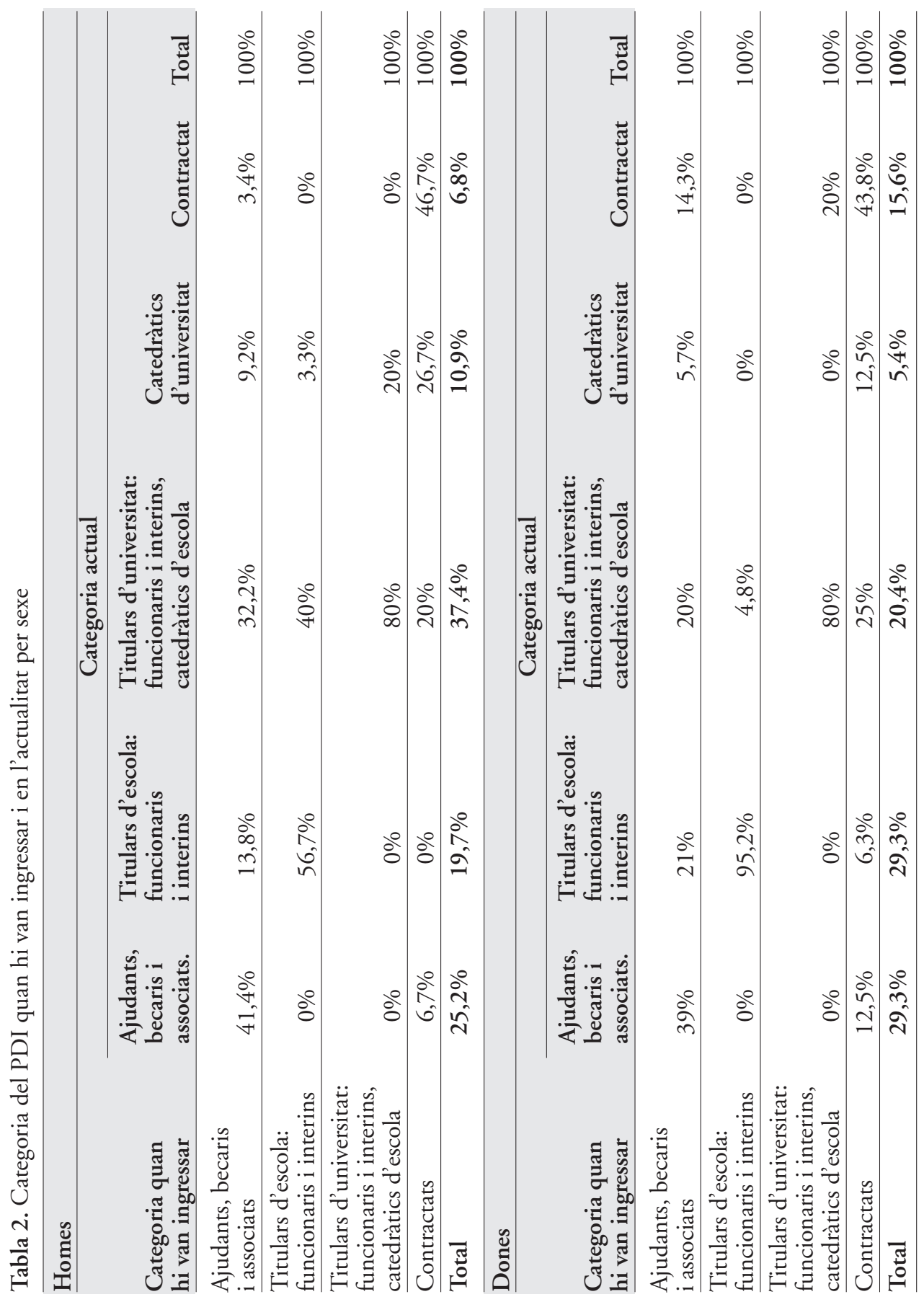


centatge més de dones que d'homes que passen a un nivell superior, però, on van? Vegem-ho: el 14\% dels homes i el 21\% de les dones són avui dia TEU; les diferències són encara més notòries per als que han arribat a TU: un 32,2\% d'homes per un $20 \%$ de dones. Entre els catedràtics, les distàncies són menors: un $9,2 \%$ enfront d'un $5,7 \%$, percentatge sempre favorable als homes. I, entre els contractats, hi torna a haver contrastos importants: el 3,4\% són ara contractats entre els homes que van entrar com a becaris, ajudants o associats, $\mathrm{i}$ entre les dones constitueixen el 14,3\%. Les diferències en les trajectòries entre homes i dones són evidents si mirem aquesta categoria inicial: hi ha més dones que agumenten de categoria, però van a llocs inferiors que els dels seus companys masculins.

El PDI TEU. És aquell un comportament específic del grup PDI que va iniciar la seva tasca docent $\mathrm{i}$ investigadora com a ajudant, becari i/o associat? Tot indica que no, ja que el comportament diferencial pel que fa a la promoció entre homes i dones es torna a repetir d'una manera persistent per a la resta de categories inicials d'entrada a la Universitat. Vegem-ne més exemples: d'entre el PDI que entra com a TEU (interí o no), els homes augmenten de categoria en un $43,3 \%$ i les dones, en un $4,8 \%$. Les dones que van entrar com a TEU continuen estan en aquest nivell en un $95,2 \%$ dels casos. O, el que és el mateix, pràcticament cap de les dones d'aquesta categoria no ha anat més amunt. A més a més, aquesta diferència també té un apunt important: mentre que el 3,3\% d'homes ha arribat a ser CU, cap dona no ha aconseguit el màxim nivell acadèmic. S'ha de tenir en compte que els anys d'entrada d'aquestes dones, i en general de les categories TEU, TU i CU, tant per a homes com a per a dones, representen un espai cronològic molt ampli, és a dir que no estan concentrats en el temps, la qual cosa produeix un biaix diferent de si, per exemple, la majoria de dones que entren com a TEU ho fessin al llarg dels darrers cinc anys. El col-lectiu femení que actualment és TEU i que va entrar també a la Universitat amb la mateixa categoria presenta una mediana de 1993 (el mateix cas per als homes), és a dir, la meitat de les dones TEU actuals (i dels homes) va ingressar com a TEU abans d'aquesta data, i la moda per al mateix col-lectiu és 1991 (1993 en els homes), l'any en què més dones que actualment són TEU van començar a treballar a la Universitat amb aquesta categoria. El col-lectiu femení presenta una dispersió més baixa que el masculí: 19 anys enfront de 34 anys de recorregut entre els TEU que van ingressar abans i els últims, la qual cosa ens diu que les dones TEU actuals presenten un perfil més homogeni quant a la data d'entrada.

El PDI TU. Vegem ara què ocorre amb la categoria de titulars d'universitat. D'entre els que hi van ingressar com a TU, un $80 \%$ d'homes i de dones segueixen essent TU. Però mentre que per als homes aquesta és la categoria que menys ha passat a nivells superiors, per a les dones és la de TEU. Aquí s'ha de tenir en compte un factor restrictiu important: les places de CU, les de més distinció acadèmica, són escasses $i$, per tant, la manera d'accedir-hi és molt restrictiva pràcticament en totes les àrees de coneixement. Aquestes restriccions sembla que actuen més eficaçment sobre les dones, ja que, d'entre les 
que han contestat l'enquesta i van entrar com a TU, no n'hi ha hagut cap que hagi assolit el grau de CU, mentre que un $20 \%$ dels seus companys en la mateixa situació d'ingrés ho van aconseguir.

El PDI contractat. Aquests professors i professores també presenten diferències de gènere. La majoria dels homes que van ingressar com a contractats segueixen essent contractats (el percentatge és pràcticament similar al de dones), però ells han passat més que elles a CU, un $26,7 \%$ enfront d'un $12,5 \%$, respectivament. Les dones han arribat més a TU (25\%) que els homes contractats (20\%), així com també a TEU. Finalment, gairebé el doble de dones que d'homes han passat a ser becàries, ajudants o associades. En conclusió:

a) D'una banda, hi ha menys impediments perquè la dona s'incorpori a ser PDI, atès que supera les restriccions d'entrada, però les trajectòries de promoció són diferents per als dos sexes, ja que les dones en surten penalitzades. Elles competeixen curricularment amb ells a l'hora d'accedir a la Universitat, però després es queden en els esglaons docents de menys prestigi en el camí de l'augment de categoria.

b) A la URV, les dones, en general, tenen una categoria acadèmica inferior a la dels homes i es distribueixen més entre categories inferiors, com ara ajudants i becaris, titulars d'escola i contractats. Els homes, en canvi, tenen més presència en categories superiors, com ara titulars d'universitat, catedràtics d'escola i catedràtics d'universitat.

En l'apartat següent del qüestionari, es tractà d'analitzar les diferents percepcions que tant els homes com les dones PDI tenen davant d'alguns indicadors de gènere. En primer lloc, es varen facilitar dotze afirmacions relacionades amb la percepció de gènere, i els resultats del percentatge de respostes afirmatives queden recollits a la taula 3 .

Si s'entenen aquestes afirmacions com a indicadors de la sensibilitat cap a la igualtat de gènere, considerant les respostes dels homes i les dones del PDI, podem concloure que existeix una visió generalitzada que la institució universitària és prou igualitària. És a dir, el 92,6\% dels homes i el 86,5\% de les dones del PDI consideren que «la Universitat és una institució més igualitària formalment que altres institucions privades». Malgrat aquesta visió, podríem dir-ne compartida, hi ha diferències en la percepció que volem destacar. S'observa que no hi ha el mateix grau d'acord en la percepció de diversos ítems; per exemple: el 86,5\% dels homes consideren que "l'accés igualitari a càrrecs de representació és qüestió de temps", enfront del 74,2\% de les dones. Aquesta visió majoritària en els dos col-lectius transmet la idea que l'accés de les dones als càrrecs universitaris es corregirà paral-lelament a l'ingrés de més dones a la tasca universitària. En una institució igualitària i que vetlla per la correcció de les desigualtats, això hauria de ser així, però el «disc dur» de qualsevol institució pot amagar dinàmiques de segregació de gènere que actuen per sobre de la igualtat d'oportunitats i de la meritocràcia. Els homes i les dones del PDI creuen que les dones, igual que els homes, poden exercir posicions de gestió i representació a la Universitat. Davant l'afirmació sobre si 
Tabla 3. Relació d'afirmacions. Percentatge de respostes afirmatives

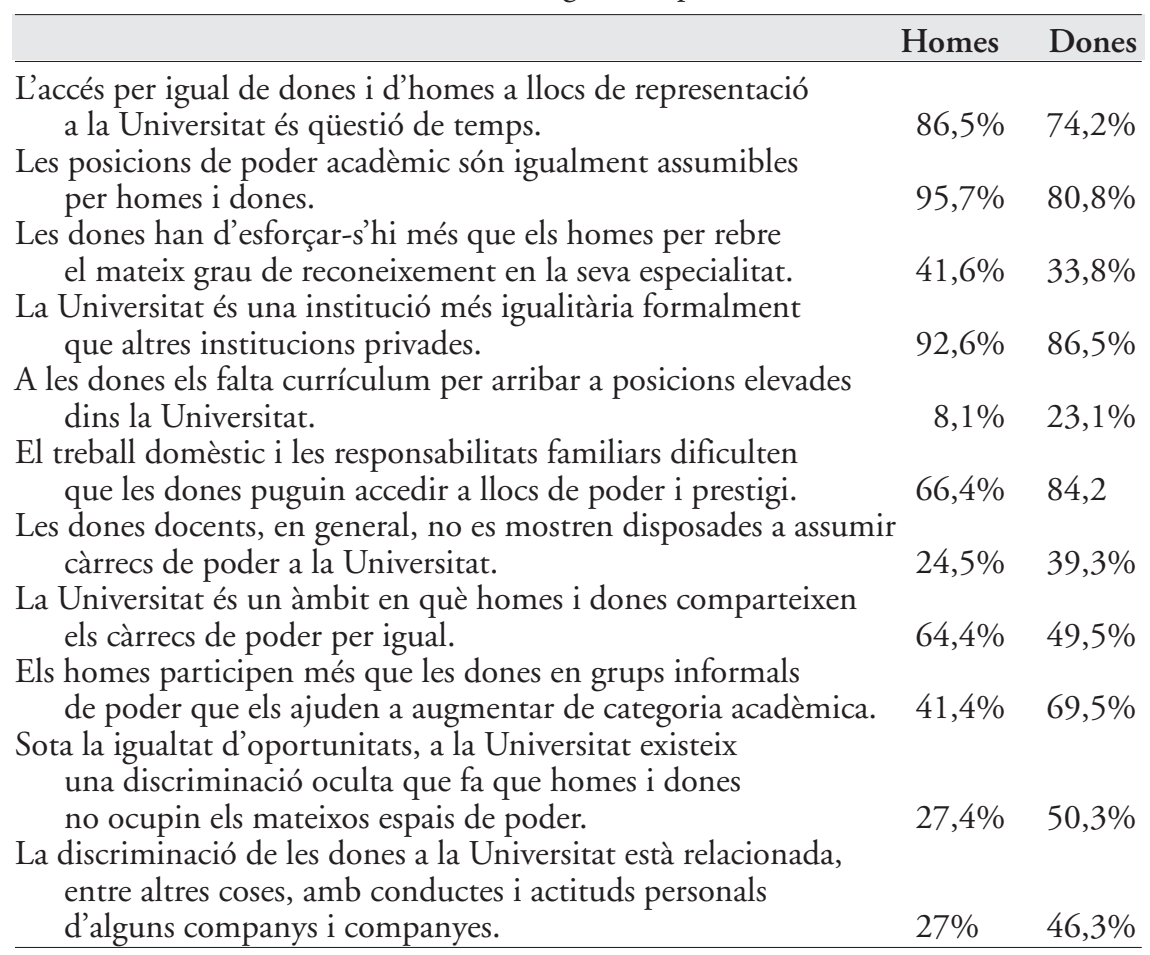

«les posicions de poder acadèmic són igualment assumibles per homes i dones», els homes ho afirmen en un 95,7\% davant del 80,8\% de les dones. Aquí els homes poden haver interpretat l'afirmació en clau d'igualtat formal, mentre que les dones ho poden haver fet en clau de restriccions d'accés al poder acadèmic. De totes maneres, l'elevat percentatge de respostes en tots dos col-lectius assenyala, un cop més, la visió igualitària de la institució. La discrepància de respostes afirmatives és més gran en les quatre afirmacions següents:

a) «Els homes participen més que les dones en grups informals de poder que els ajuden a augmentar de categoria acadèmica», les dones ho afirmen en un $69,5 \%$, davant del $41,4 \%$ dels homes.

b) «El treball domèstic i les responsabilitats familiars dificulten que les dones puguin accedir a llocs de poder i prestigi», enfront del $84,2 \%$ de les respostes afirmatives de les dones, hi trobem el $66,4 \%$ de les dels homes.

c) «Sota la igualtat d'oportunitats, a la Universitat existeix una discriminació oculta que fa que homes i dones no ocupin els mateixos espais de poder", els homes la puntuen afirmativament en un $27,4 \%$, i quasi el doble de les respostes afirmatives correspon a les dones, amb el 50,3\%. O el que és el mateix, els homes hi estan poc d'acord o gens d'acord en un $72,6 \%$. 
d) Així mateix, l'afirmació «La discriminació de les dones a la Universitat està relacionada, entre altres coses, amb conductes i actituds personals d'alguns companys i companyes» és contestada positivament pel $27 \%$ dels homes i pel $46,3 \%$ de les dones.

Com es veu, les dones del PDI tenen la percepció que existeixen factors que podríem incloure en la lògica organitzativa de tipus informal i que afecten les trajectòries professionals, i no precisament afavorint les dones. Així, la participació en grups informals, els mecanismes ocults de discriminació i les conductes dels propis membres del PDI poden considerar-se tots factors que afecten les dones i els homes PDI en el disseny de les seves carreres respectives. D'aquí que els aspectes organitzatius, poc estudiats normalment en els estudis de gènere, se'ns presenten com a hipòtesis per explorar combinats amb la càrrega de treball domèstic que suporten les dones juntament amb la disponibilitat de temps. Les dues afirmacions «A les dones els falta currículum per arribar a posicions elevades dins la Universitat» $\mathrm{i}$ «Les dones docents, en general, no es mostren disposades a assumir càrrecs de poder a la Universitat» no presenten significació estadística, tot i la variació en el percentatge de respostes. És interessant observar aquesta diferència de percepció entre els homes i les dones. Un $23 \%$ de dones té la percepció que els falten mèrits curriculars per ocupar les posicions més elevades a la Universitat, enfront del 8\% dels homes. Tanmateix, si tant els homes com les dones majoritàriament perceben que no és una qüestió de mèrits curriculars, per què hi ha diferències en la composició de les categories docents entre el PDI? I per què els homes tendeixen a ocupar els càrrecs de gestió i representació en què es prenen més decisions?

A continuació, es van proporcionar diferents mesures d'acció positiva ${ }^{9}$, amb la finalitat de conèixer el grau d'acord o desacord amb aquestes.

Els resultats més significatius de la taula 4 són aquells que fan referència a les mesures paritàries: el 65,2\% dels homes estan poc o gens d'acord amb el fet que tots els òrgans de gestió hagin de ser paritaris, davant del 58,3\% de dones que sí que hi estan d'acord, molt o totalment d'acord. Mantenen, així mateix, una diferència similar en les mesures 2 i 3 , que fan referència a la paritat en tots els òrgans de representació. I en l'afirmació que tots els equips de recerca haurien de ser paritaris, el 73,6\% dels homes hi estan poc o gens d'acord, enfront del 54,7\% de les dones, que tampoc hi estan d'acord. On s'observa

8. Encara que no ha estat objecte d'exposició en aquest article, veiem les dades de composició del claustre universitari actual: el rector, el secretari general i el gerent són homes; al Consell de Direcció hi ha 5 dones i 4 homes; degans i directors d'escola: 9 homes i 3 dones; directors de departament: 15 homes i 7 dones; professorat doctor de cossos docents universitaris: 44 homes i 17 dones; professorat no doctor de cossos docents universitaris i altres: 10 homes i 10 dones; alumnes: 20 homes i 9 dones (sense cobrir 24 vacants), i personal d'Administració i Serveis: 13 homes i 11 dones.

9. Aquestes mesures es van elaborar a partir de les propostes realitzades pel personal PDI entrevistat en la fase prèvia al disseny del qüestionari. Se'n van seleccionar aquelles propostes que van aparèixer més reiteradament en les entrevistes en profunditat. 
Tabla 4. Mesures d'acció positives sobre les dones a la Universitat

\begin{tabular}{lccccc}
\hline & \multicolumn{2}{c}{ Homes } & & \multicolumn{2}{c}{ Dones } \\
\cline { 2 - 3 } \cline { 5 - 6 } & $\begin{array}{l}\text { Poc o gens } \\
\text { d'acord (\%) }\end{array}$ & $\begin{array}{l}\text { D'acord o } \\
\text { totalment } \\
\text { d'acord (\%) }\end{array}$ & & $\begin{array}{l}\text { Poc o gens } \\
\text { d'acord (\%) }\end{array}$ & $\begin{array}{l}\text { D'acord o } \\
\text { totalmen } \\
\text { d'acord (\%) }\end{array}$ \\
\hline Mesura 1 & 65,2 & 34,8 & & 41,7 & 58,3 \\
Mesura 2 & 63,2 & 36,8 & & 40,4 & 59,6 \\
Mesura 3 & 73,6 & 26,3 & & 54,7 & 45,4 \\
Mesura 4 & 66,0 & 33,9 & & 36,2 & 63,8 \\
Mesura 5 & 83,4 & 16,6 & & 81,5 & 18,6 \\
Mesura 6 & 27,0 & 73,1 & & 23,4 & 74,8 \\
Mesura 7 & 52,1 & 47,8 & & 42,4 & 52,5 \\
Mesura 8 & 61,7 & 38,2 & & 53,7 & 42,1 \\
Mesura 9 & 52,8 & 47,2 & & 42,8 & 52 \\
Mesura 10 & 15,9 & 84,1 & & 9,9 & 87 \\
Mesura 11 & 1,9 & 98,1 & 3,2 & 97,5 \\
\hline
\end{tabular}

M-1: Tots els òrgans de gestió haurien de ser paritaris.

M-2: Tots els òrgans de representació haurien de ser paritaris.

M-3: Els equips de recerca haurien de ser paritaris.

M-4: Les comissions que decideixen els concursos de places docents haurien de ser paritaris.

M-5: A igualtat de mèrits en els concursos de places docents, s'hauria de triar una dona davant un home.

M-6: A cada universitat hi hauria d'haver un observatori sobre la igualtat d'homes i dones.

M-7: Hauria d'oferir obligatòriament uns determinats crèdits de lliure elecció relacionats amb la igualtat d'homes i dones.

M-8: Els departaments haurien d'oferir una sèrie de crèdits en relació amb la igualtat d'homes i dones.

M-9: Hauria de formar el personal docent sobre la forma d'incloure la perspectiva de gènere en els programes de les assignatures.

M-10: Ha d'assegurar un ús no sexista del llenguatge.

M-11: Hauria de desenvolupar, de forma prioritària, un programa de mesures per conciliar la vida laboral i la familiar.

una unanimitat més gran entre els dos col-lectius és en la mesura 11, on es proposa la necessitat que la Universitat desenvolupi un programa per conciliar la vida laboral i la familiar. En aquest cas, tant els homes com les dones manifesten el seu assentiment amb un 98,1\% i un 97,5\%, respectivament. Aquesta és l'única acció on els homes puntuen per sobre de les dones (en un $0,6 \%)$ en mesures d'acció positiva. També hi ha proximitat en les respostes davant la possibilitat que en cada universitat existeixi un observatori per a la igualtat, davant del 73,1\% dels homes que hi estan d'acord o molt d'acord i del 74,8\% de dones que també hi estan.

A partir de les respostes obtingudes en la bateria de preguntes sobre l'acció positiva a la Universitat, vam elaborar uns índexs: l'índex de funcionament paritari (IFP), l'índex de sensibilització de gènere (ISG), l'índex d'igualtat formal (IIF) i l'índex general de percepció de gènere (IGPG). Els valors de tots 
aquests índexs oscil-len entre 0 i 1 , i la interpretació que se’n fa és la següent: els valors pròxims a 0 indiquen inexistència o màxim desacord (segons els casos), mentre que els valors propers a 1 indiquen existència o màxim acord. Els índexs han estat construïts a partir de l'expressió següent:

$$
I=\frac{\sum_{i}^{n} x_{i}-m i n}{m a ̀ x-m i ́ n}
$$

On $\sum_{i}^{n} x_{i}$ és el sumatori de totes les puntuacions obtingudes pels individus en els ítems; min. és la puntuació mínima que es pot obtenir a les escales i màx. és la puntuació màxima que s'hi pot obtenir.

L'índex general de percepció de gènere és el resultat de la mitjana ponderada dels tres índexs anteriors, tenint en compte que s'ha considerat de més pes a menys pes, l'IFP, l'IIF i l'ISG, en la ponderació. Vegem en el quadre 1 els tipus d'indicadors sintètics construïts a partir dels grups de mesures proposades:

Quadre 1.

Tipus de mesures Índexs

M-1: Tots els òrgans de gestió haurien de ser paritaris. Índex de funcionament paritari (IFP).

M-2: Tots els òrgans de representació haurien

de ser paritaris.

M-3: Els equips de recerca haurien de ser paritaris.

M-4: Les comissions que decideixen els concursos

de places docents haurien de ser paritaris.

M-5: A igualtat de mèrits en els concursos de places docents, s'hauria de triar una dona davant un home.

M-7: Hauria d'oferir obligatòriament uns crèdits determinats de lliure elecció relacionats amb Índex de sensibilització la igualtat d'homes i dones. de gènere (ISG).

M-8: Els departaments haurien d'oferir una sèrie de crèdits en relació amb la igualtat d'homes

i dones.

M-9: Hauria de formar el personal docent sobre la forma d'incloure la perspectiva de gènere en els programes de les assignatures.

M-6: A cada universitat hi hauria d'haver un Índex d'igualtat formal (IIF). observatori sobre la igualtat d'homes i dones.

M-10: Ha d'assegurar un ús no sexista del llenguatge.

M-11: Hauria de desenvolupar, de forma prioritària, un programa de mesures per conciliar la vida laboral i familiar. $\mathrm{IFP}+\mathrm{ISG}+\mathrm{IIF}=\quad$ Índex general de percepció de gènere (IGPG). 
Tabla 5. Índex de funcionament segons sexe

\begin{tabular}{lccl}
\hline & Per sota de la mitjana o igual & Per sobre de la mitjana & Total \\
\hline Home & 110 & 60 & 170 \\
& $64,7 \%$ & $35,3 \%$ & $100,0 \%$ \\
\hline Dona & 62 & 101 & 163 \\
& $38,0 \%$ & $62,0 \%$ & $100,0 \%$ \\
\hline Total & 172 & 161 & 333 \\
& $51,7 \%$ & $48,3 \%$ & $100,0 \%$ \\
\hline
\end{tabular}

A partir de les cinc primeres mesures, es va establir un index de funcionament paritari (IFP). Els valors finals per a cada individu poden oscil.lar entre el valor zero, desacord més absolut, i el valor 1, el cas d'aquells amb un grau més elevat d'acord, o acord absolut, amb les mesures de paritat que componen l'índex. La distribució de freqüències d'aquest índex de paritat per a tot el PDI ens informa del fet que la meitat de les respostes dels entrevistats se situen per sota de la puntuació 0,44 (mediana) i la mitjana és de 0,486. Ens interessa ara observar si hi ha diferències significatives entre la percepció dels homes i la de les dones del PDI:

A la taula 5 , s'hi observen les diferències en l'IFP segons el sexe del PDI. Veiem que el $64,7 \%$ dels homes puntuen per sota de la mitjana en aquest índex, mentre que les dones es distribueixen en un 38\% per al valor 0 i el $62 \%$ per al valor màxim. La prova khi quadrat ens indica associació estadística entre les dues variables. Podem concloure que el col-lectiu de dones PDI està més d'acord a impulsar les mesures paritàries abans mencionades que els homes PDI. En conclusió, les dones PDI reclamen una intervenció paritària pel que fa a les mesures contemplades en l'anàlisi.

L'index d'igualtat formal (IIF). La mitjana de l'IIF per a tot el PDI és de 0,7638 , fet que manifesta un elevat grau d'acord amb les mesures que componen l'índex (vegeu el quadre 1). Tanmateix, si observem la percepció del col.lectiu d'homes i del de dones per separat, hi observem que hi ha diferències de percepció, és a dir, podem concloure que homes i dones discrepen en les seves respostes. Com veiem a la taula 6 , un $54,1 \%$ d'homes puntua per sota de la mitjana de l'índex, mentre que un $57,7 \%$ de dones puntua per sobre. Això no vol dir que els homes majoritàriament no estiguin d'acord amb les mesures proposades, sinó que l'adhesió a les propostes no té tanta intensitat com en les

Tabla 6. Índex d'igualtat formal segons sexe

\begin{tabular}{lccl}
\hline & Per sota de la mitjana o igual & Per sobre de la mitjana & Total \\
\hline \multirow{2}{*}{ Home } & 92 & 78 & 170 \\
& $54,1 \%$ & $45,9 \%$ & $100,0 \%$ \\
\hline Dona & 69 & 94 & 163 \\
& $42,3 \%$ & $57,7 \%$ & $100,0 \%$ \\
\hline Total & 161 & 172 & 333 \\
& $48,3 \%$ & $51,7 \%$ & $100,0 \%$ \\
\hline
\end{tabular}


Tabla 7. Índex de sensibilització de gènere segons sexe

\begin{tabular}{lccl}
\hline & Per sota de la mitjana o igual & Per sobre de la mitjana & Total \\
\hline \multirow{2}{*}{ Home } & 89 & 81 & 170 \\
& $52,4 \%$ & $47,6 \%$ & $100,0 \%$ \\
\hline Dona & 67 & 69 & 163 \\
& $41,1 \%$ & $58,9 \%$ & $100,0 \%$ \\
\hline Total & 156 & 177 & 333 \\
& $46,8 \%$ & $53,2 \%$ & $100,0 \%$ \\
\hline
\end{tabular}

dones. De fet, la puntuació mitjana dels homes en aquest IIF és de 0,7453 , una xifra elevada si es té en compte que el valor màxim de l'índex és 1 . Entre les dones, la puntuació mitjana és de 0,7837 , sensiblement superior a la dels homes.

En tercer lloc, hem agrupat les mesures 7, 8 i 9 (vegeu el quadre 1) per crear un indicador sintètic de sensibilització que hem anomenat index de sensibilització en gènere (ISG) i que, conceptualment, té a veure amb la intervenció que es podria fer des de diferents àmbits de gestió de la Universitat, amb l'objectiu de sensibilitzar i formar la comunitat universitària en qüestions relatives al gènere. Com els índexs anteriors, l'ISG varia entre el valor $0 \mathrm{i}$ el valor 1 . El valor de la mitjana d'aquest índex per a tot el PDI és de 0,5209. Per sexes, són els homes els que presenten una mitjana més baixa, és a dir, hi ha menys homes que estiguin d'acord o molt d'acord amb la implementació de les mesures de l'ISG: 0,4926 de mitjana enfront de les dones, que puntuen 0,5517. Vegem ara la distribució percentual d'homes i de dones tenint en compte els que es troben per sota de la mitjana i els que s'hi troben per sobre:

A la taula 7 , s'hi observa una certa diagonalització en els percentatges de respostes: el 52,4\% dels homes mostra una puntuació per sota de la mitjana, mentre que el $58,9 \%$ puntua per sobre de la mitjana. Un cop més, les diferències són significatives entre homes i dones, és a dir, els membres dels dos sexes tenen percepcions diferents en relació amb la implementació de sensibilització de gènere que haurien de realitzar diferents òrgans de la Universitat.

Posteriorment, hem construït un índex global anomenat index general de percepció de gènere (IGPG), que pretén resumir la informació dels tres índexs anteriors ponderant la puntuació en cadascun. Hem donat el valor màxim de ponderació a l'IFP, seguit de l'IIF i, finalment, l'ISG, atès que les mesures que componen els diversos índexs representen un compromís més gran o més petit amb les intervencions de polítiques paritàries.

Així, hem considerat que l'aposta per la intervenció és més gran si es puntua favorablement en les mesures 1 a la 5 (mesures IFP) i més petita en el cas de les mesures que componen l'ISG. Tenint en compte aquesta ponderació, el valor de la mitjana de l'IGPG és de 0,6250. Els homes puntuen un 0,5821 de mitjana, enfront de les dones, que puntuen un 0,6682 de mitjana. A la taula 8 , s'hi observa que el $62 \%$ de les dones PDI puntuen per sobre de la mitjana de l'índex, mentre que el 64,7\% dels homes puntuen per sota. Les diferències són significatives estadísticament parlant, segons el test khi quadrat. 
Tabla 8. Índex de sensibilització de gènere segons sexe

\begin{tabular}{lccl}
\hline & Per sota de la mitjana o igual & Per sobre de la mitjana & Total \\
\hline \multirow{2}{*}{ Home } & 110 & 60 & 170 \\
& $64,7 \%$ & $35,3 \%$ & $100,0 \%$ \\
\hline Dona & 62 & 101 & 163 \\
& $38,0 \%$ & $62,0 \%$ & $100,0 \%$ \\
\hline Total & 172 & 161 & 333 \\
& $51,7 \%$ & $48,3 \%$ & $100,0 \%$ \\
\hline
\end{tabular}

Tabla 9. Resum de les mitjanes per a cada índex

\begin{tabular}{lcccccccc}
\hline & IFP & Desv. & IIF & Desv. & ISG & Desv. & IGPG & Desv. \\
\hline Tot el PDI & 0,486 & & 0,7638 & & 0,5209 & & 0,6250 & \\
\hline Dones & 0,5514 & 0,221 & 0,7837 & 0,160 & 0,5517 & 0,240 & 0,6682 & 0,156 \\
\hline Homes & 0,4286 & 0,224 & 0,7453 & 0,168 & 0,4926 & 0,239 & 0,5821 & 0,164 \\
\hline Diferència & 0,1228 & & 0,0384 & & 0,0591 & & 0,0861 & \\
\hline
\end{tabular}

Les mitjanes resumides per a cada índex segons sexe s'expressen a la taula 9.

Vegem ara si hi ha diferències en l'IGPG entre els col-lectius femení i masculí segons l'edat del PDI, la categoria actual ${ }^{10}$ i l'índex d'activitat ${ }^{11}$. Com es pot veure a la taula 9 , les respostes que donen homes i dones són sensiblement distintes, però també s'hi observen diferències remarcables dins dels propis col-lectius d'homes o de dones segons l'edat, la categoria docent o el grau d'activitat. El grup que més puntua en l'IGPG és el de les dones més joves (amb una mitjana de 0,688 ), el del grup docent $A$ (ajudants, becàries $\mathrm{i}$ associades, amb una mitjana de 0,720 ) i el de les que tenen una activitat per sota de la mitjana (amb una mitjana de 0,702). A més a més de ser el grup que més sensibilitat mostra en els indicadors que hem mesurat, també és el més sensible dins del propi col-lectiu de dones PDI. Si observem internament el collectiu d'homes PDI, també són els més joves (amb una mitjana de 0,65 ) i els que tenen menys activitat (amb una mitjana de 0,597) els que puntuen més, aquesta vegada acompanyats de la categoria docent $\mathrm{E}$ (PDI contractat), seguits de molt a prop de la categoria A. En destaquem que, a mesura que

10. Categoria docent: A: ajudants, becaris, becàries, associats i associades; B: titulars d'escola: funcionaris i interins; C: titulars d'universitat: funcionaris i interins, catedràtics d'escola; D: catedràtics d'universitat, i E: contractats i contractades.

11. L'índex d'activitat és una mesura "qualitativa» de la tasca del professorat que indica si cada PDI ha fet o no un tipus d'activitat i la seva posició en una escala referent a aquesta relació dicotòmica $(0=$ sense cap activitat; 1 = màxima activitat $)$. Les activitats ponderades en aquest índex són, d'una banda, els articles publicats, la participació en llibres publicats, els llibres publicats i la coordinació de llibres publicats. D’altra banda, hi ha la direcció de tesis, i, per últim, l'assistència a congressos, a cursos d'innovació docent i a activitats de transferència de coneixements. 
Tabla 10. Percepció de gènere segons sexe, edat, classe docent i activitat ${ }^{1}$

\begin{tabular}{|c|c|c|c|c|c|c|}
\hline & \multicolumn{2}{|c|}{$\begin{array}{l}\text { Percentatge de respostes } \\
\text { per sota de la mitjana } \\
\text { de tot el PDI }\end{array}$} & \multicolumn{2}{|c|}{$\begin{array}{l}\text { Percentatge de respostes } \\
\text { per sobre de la mitjana } \\
\text { de tot el PDI }\end{array}$} & \multicolumn{2}{|c|}{$\begin{array}{l}\text { Mitjanes } \\
\text { dels grups }{ }^{1}\end{array}$} \\
\hline & Homes & Dones & Homes & Dones & Homes & Dones \\
\hline \multicolumn{7}{|l|}{ Grups d'edat } \\
\hline Fins a 30 anys & $52 \%$ & $28 \%$ & $48 \%$ & $72 \%$ & 0,625 & 0,688 \\
\hline 31 a 40 anys & $64,6 \%$ & $41,2 \%$ & $35,4 \%$ & $58,8 \%$ & 0,583 & 0,663 \\
\hline Més de 40 anys & $68,8 \%$ & $38,2 \%$ & $31,3 \%$ & $61,8 \%$ & 0,568 & 0,669 \\
\hline \multicolumn{7}{|l|}{ Classes docents } \\
\hline A & $53,8 \%$ & $22,2 \%$ & $46,2 \%$ & $77,8 \%$ & 0,606 & 0,720 \\
\hline B & $62,1 \%$ & $37,8 \%$ & $37,9 \%$ & $62,2 \%$ & 0,583 & 0,681 \\
\hline $\mathrm{C}$ & $72,9 \%$ & $51,5 \%$ & $27,1 \%$ & $48,5 \%$ & 0,558 & 0,602 \\
\hline $\mathrm{D}$ & $81,3 \%$ & $75 \%$ & $18,8 \%$ & $25 \%$ & 0,531 & 0,552 \\
\hline $\mathrm{E}$ & $57,1 \%$ & $37 \%$ & $42,9 \%$ & $63 \%$ & 0,613 & 0,667 \\
\hline \multicolumn{7}{|c|}{ Index d'activitat $^{2}$} \\
\hline \multicolumn{7}{|c|}{ Per sota de } \\
\hline \multicolumn{7}{|l|}{ Per sobre de } \\
\hline la mitjana & $69,6 \%$ & $46,3 \%$ & $30,4 \%$ & $53,7 \%$ & 0,572 & 0,635 \\
\hline
\end{tabular}

augmenten l'edat i la categoria docent, els professors, tant homes com dones, puntuen menys en l'IGPG. Constatem també que el percentatge de dones que puntua per sobre de la mitjana sempre és més elevat que el dels homes per a tots els subgrups considerats: en tots els subgrups la diferència entre dones i homes que se situen per sobre de la mitjana de tot el PDI és de més de 20 punts percentuals, tret del grup de catedràtics i catedràtiques, en què la diferència entre dones i homes és de 6 punts percentuals. On més diferències hi ha entre els grups és entre els més grans de quaranta anys (un 30\% més de dones que d'homes puntuen per sobre) i entre els de la categoria A (ajudants, becaris i associats), en el qual hi ha un 32\% més de dones que d'homes que puntuen per sobre.

\section{Gènere i transversalitat en la docència}

Hi ha diferents combinacions en el tractament de la temàtica de gènere en els plans d'estudis dels ensenyaments a la Universitat. Des de l'aposta per estudis propis de gènere en format de màster o postgrau, fins a l'opció de la transversalitat de gènere als estudis. Introduir la perspectiva de gènere als estudis significa 
que aquesta variable entri com a factor explicatiu dels comportaments, i que la realitat social, econòmica, tecnològica i científica en general pugui ser abordada i explicada ${ }^{12}$ en termes de gènere. En aquesta línia, un dels objectius marcats per aquesta recerca va ser analitzar els plans d'estudi per verificar que els avenços acadèmics de les diferents disciplines sobre aquesta problemàtica han estat incorporats als coneixements que transmet la Universitat. Per assolir-lo, hem analitzat la docència que s'ha fet a la URV en els darrers deu anys. Fem avinents, en aquesta darrera part de l'article, el tractament que, de la desigualtat per raó de gènere, es dóna en el contingut curricular dels diferents ensenyaments de la URV.

Hem seleccionat quatre plans d'estudis (dos de ciències socials i dos d'humanitats), perquè les àrees a les quals pertanyen són considerades més afins als estudis de gènere. N'hem escollit dues llicenciatures, una diplomatura i un segon cicle. De l'àmbit de ciències socials, una diplomatura, Relacions Laborals i la llicenciatura en Pedagogia. De l'àmbit d'humanitats, n'hem seleccionat Geografia, llicenciatura adaptada als crèdits europeus i en fase experimental, i el segon cicle d'Antropologia Social i Cultural. De l'àmbit de les Ciències Socials, n'hem analitzat 57 assignatures del Pla d'Estudis de 2002 de la diplomatura en Relacions Laborals. Hem trobat un total de cinc assignatures que inclouen la temàtica de gènere en els seus programes. Les temàtiques tractades són: treball productiu i reproductiu, règim especial del servei domèstic, maternitat i excedència laboral, i prevenció laboral i protecció de la maternitat. Per tant, trobem dos temes de caràcter jurídic, dos de prevenció laboral i un sobre les característiques de gènere al mercat de treball.

Entre les referències bibliogràfiques, n'hi ha un total de sis. Dues de les assignatures inclouen temes de gènere, però no bibliografia. Dues més inclouen bibliografia general i específica sobre els temes de gènere i una altra inclou només bibliografia específica. També de l'àmbit de les Ciències Socials, de la llicenciatura en Pedagogia, del Pla d'Estudis de 2002, hem analitzat 42 assignatures. L'anàlisi mostra la inexistència de cap assignatura relativa a temes com ara l'androcentrisme a la ciència, la professió de mestre com a treball feminitzat, el sexisme a les aules, temes sobre coeducació i d'altres relatius a la dimensió de gènere. La presència d'aquest tipus d'assignatures és present als currículums d'altres universitats. En destaquem que s'imparteixen dues assignatures que inclouen temàtica de gènere en els seus programes: Models Didàctics Derivats dels Grans Pedagogs i Pedagogues dels Segles XIX i XX i Sociologia de la Dona i Cultura Intersexual a l'Escola. Impacte del Feminisme. Respecte a la bibliografia, les assignatures amb temàtica de gènere inclouen bibliografia obligatòria sobre el tema. Les temàtiques són la feminització de la docència i el treball femení. Hi ha tres assignatures més que inclouen en la bibliografia obligatòria temàtiques de gènere sobre currícu-

12. Explicada en el sentit més causal del terme, és a dir, que el gènere ens permeti establir relacions d'associacions entre diferents factors i que aquestes relacions puguin ser mesurades. 
lum ocult, feminització de la docència i dues monografies sobre dues pedagogues i coeducació. Existeixen cinc referències en quatre assignatures; d'aquestes referències, quatre són sobre bibliografia general i una sobre bibliografia específica.

En l'àmbit de les humanitats, hi hem analitzat les assignatures de la llicenciatura de Geografia i el segon cicle de la llicenciatura en Antropologia Social i Cultural. La llicenciatura en Geografia, del Pla d'Estudis de 2001, està dissenyada de forma experimental per adaptar-la al sistema de crèdits europeus. Hem analitzat un total de 46 assignatures. No hi ha cap programa de cap assignatura que inclogui temes de gènere en aquesta titulació. Tampoc no hi hem trobat cap referència bibliogràfica, ni obligatòria ni específica. Entre els objectius d'una assignatura, hi ha "estudiar els moviments socials a partir de la dècada dels 60", entenem que hi deu existir alguna referència als moviments feministes d'aquesta època, tot i que no sabem del cert si és així. Hi ha referències sobre temàtica de gènere en les pràctiques de caire demogràfic en una assignatura.

De la llicenciatura d'Antropologia Social i Cultural, del Pla d'Estudis que data de 2001, n'hem analitzat 28 assignatures. N'hi ha dues que contenen la temàtica de gènere en el programa. Els temes són «L'estructura de la població: estructura per edat $\mathrm{i}$ sexe» $\mathrm{i}$ «Espais de treball, espais de consum: de cuineres $\mathrm{i}$ cuiners, de dins i de fora». Les temàtiques estan relacionades amb aspectes demogràfics i amb alimentació i cultura. No hi hem trobat cap referència bibliogràfica, ni en la bibliografia genèrica o obligatòria, ni en la bibliografia específica sobre qüestions de gènere.

En relació amb la docència, es pot afirmar que la URV no ofereix assignatures amb contingut específic de gènere. L'absència n'és la característica general. Els quatre plans d'estudi analitzats són relativament recents (tres de 2002 i un de 2001). Tot i així, no n'hi ha cap que ofereixi actualment assignatures específiques de gènere. Existeix una assignatura optativa de 6 crèdits, Sexe, Gènere, Amor, vinculada a l'àrea d'Antropologia Social. Els breus continguts descriptius es refereixen a "Homes i dones en les societats no occidentals. Dones i homes en la societat occidental-industrial. Conceptes antropològics de sexe i gènere. L'amor romàntic i la seva evolució. Anàlisi antropològica del matrimoni. Sexe ritualitzat i imaginari sexual, etc.». És l'única assignatura específica de gènere a tota la URV. Existeixen referències concretes a la perspectiva de gènere en alguns temes d'algunes assignatures, certa bibliografia general i específica, que semblen més reflex de l'esforç individual del professorat, que no pas resultat d'una intencionalitat específica d'introduir la perspectiva de gènere en els plans d'estudi, tal com ho confirma l'afirmació de professors, i sobretot de professores, que responien a la pregunta «Introdueixen continguts de gènere a la seva assignatura?». Només el $12 \%$ de les professores i el $10 \%$ dels professors enquestats van respondre afirmativament. On la divergència en les respostes és més elevada és en aquella que inclou la perspectiva de gènere en les assignatures impartides "de forma improvisada». Davant del 12,3\% de les dones, el 6\% dels PDI masculins afir- 
ma que hi inclou temàtica de gènere sense un treball previ. En vista d'aquest indicador, podem concloure que la temàtica de gènere és molt poc present als currículums de la Universitat. El màster Especialista en Gènere i Diversitat realitzat el curs 2004-2005 és l'única referència de curs d'especialització, màster o estudi de postgrau que amplia la formació bàsica de l'alumnat en l'àmbit específic de gènere o s'ocupa de la formació i l'actualització dels coneixements dels professionals en exercici, requisits imprescindibles per dotar-los d'eines necessàries per eliminar les desigualtats de gènere i la consolidació d'una ciutadania activa.

\section{Conclusions}

L'anàlisi de les percepcions del col-lectiu professional acadèmic ens dóna informació sobre quin és l'imaginari social i sobre quines estructures mentals s'assenten les seves accions més quotidianes. Les respostes a l'enquesta que hem realitzat a la URV ens permeten conèixer les tendències $\mathrm{i}$ els posicionaments de les dones i dels homes que componen el col-lectiu PDI en relació amb la situació de gènere a la Universitat. Si s'entenen aquestes afirmacions com a indicadors de la sensibilitat cap a la igualtat de gènere, podem afirmar que existeix una visió generalitzada que la institució universitària és prou igualitària, tot i que hi ha diferències en les percepcions d'homes i de dones respecte a la igualtat d'oportunitats a la Universitat. Les dones donen més importància, amb gairebé 30 punts percentuals de diferència respecte als homes, als grups informals en la promoció (69,5\% del col-lectiu femení així ho afirma), al pes del treball domèstic i reproductiu en la carrera professional (84,2\%), a l'existència d'un tipus de discriminació oculta que dificulta que elles arribin als llocs de poder i prestigi $(50,3 \%)$ i a la influència d'actituds i conductes dels companys i les companyes en la discriminació $(46,3 \%)$.

El col-lectiu femení del PDI té la percepció que les seves trajectòries professionals estan influenciades per una sèrie de factors que escapen a l'organització formal de la Universitat, per exemple: les càrregues domèstiques i reproductives i la disponibilitat de temps. Però també hi apareixen amb força els factors organitzatius i la pròpia lògica de l'organització, on el poder simbòlic i indirecte condiciona el context d'actuació dels grups, en aquest cas dels grups significatius de dones i d'homes. El treball d'aquests col-lectius a la Universitat es troba recorregut per les lògiques de control i apropiació de recursos i decisions, lògiques en les quals les dones són escassament presents, lògiques que determinen l'accés i les trajectòries professionals. Potser les jerarquies de gènere en el coneixement científic es poden explicar en part pel control que els individus tenen d'aquestes lògiques organitzatives i de poder, hipòtesi que quedaria per contrastar en nous estudis sobre gènere en la universitat.

Amb els tres índexs creats, es pot observar la diferència en la percepció dels dos col-lectius. L'índex de funcionament paritari (IFP), l'índex d'igualtat formal (IIF) i l'índex de sensibilització en gènere (ISG) reflecteixen els tres tipus de mesures contemplats i es resumeixen en un índex global: l'índex general de 
percepció de gènere (IGPG). Hi ha diferències significatives entre la percepció d'homes i de dones en cadascun dels índexs que componen l'IGPG global. Respecte a la paritat, l'índex de funcionament paritari mostra que el col.lectiu de dones PDI està més d'acord a impulsar les mesures paritàries que no pas els homes PDI. Les dones PDI reclamen una intervenció paritària pel que fa als òrgans de gestió i representació, als equips de recerca, a les comissions de places i a la selecció docent d'acció positiva.

L'índex d'igualtat formal (IIF) mostra un grau de respostes afirmatives, tant d'homes com de dones. No obstant això, l'adhesió a les propostes per part dels homes no té tanta intensitat com en les dones. De fet, la puntuació mitjana dels homes en aquest IIF és de 0,7453, una puntuació elevada si es té en compte que el valor màxim de l'índex és 1 . Entre les dones, la puntuació mitjana és de 0,7837 , sensiblement superior a la dels homes. Les mesures a les quals les dones s'adhereixen amb més intensitat són la creació d'un observatori de la igualtat i la necessitat que la Universitat asseguri un ús no sexista del llenguatge i desenvolupi mesures de conciliació de la vida laboral i familiar. L'índex de sensibilització en gènere (ISG) es refereix a la intervenció que es podria fer des de diferents àmbits de gestió de la Universitat, amb l'objectiu de sensibilitzar i formar la comunitat que en forma part en qüestions relatives al gènere. En aquest índex és on les puntuacions són més baixes per als dos col-lectius. Homes i dones tenen percepcions diferents en relació amb la implementació de sensibilització de gènere que haurien de realitzar diferents òrgans de la Universitat. L'índex general de percepció de gènere (IGPG) resumeix la informació dels tres índexs anteriors, ponderant la puntuació en cadascun. El valor màxim de ponderació correspon a l'IFP, seguit de l'IIF i, finalment, l'ISG, atès que les mesures que componen els diversos índexs representen un compromís més gran o més petit amb les intervencions de polítiques paritàries. Tenint en compte aquesta ponderació, el valor de la mitjana de l'IGPG és de 0,6250. Els homes puntuen de mitjana un 0,5821 , enfront de les dones, que puntuen de mitjana 0,6682. Segons l'IGPG, les percepcions són més diferenciades respecte a l'índex de funcionament paritari i a l'índex de sensibilització en gènere, mentre que, respecte a l'índex d'igualtat formal (IIF), les percepcions dels col-lectius s’aproximen més. Les dones entenen que són necessàries mesures paritàries $\mathrm{i}$ de sensibilització en gènere més que no pas el col-lectiu masculí. Tanmateix, les mesures d'igualtat formal també tenen el suport majoritari dels homes (per sobre de la mitjana) i és l'únic índex que mostra aquest posicionament del col-lectiu masculí.

En tant que grups, són les dones més joves les que puntuen més alt en l'IGPG (amb una mitjana de 0,688 ), del grup docent A (ajudants, becàries i associades, amb una mitjana de 0,720 ) i les que tenen una activitat per sota de la mitjana (amb una mitjana de 0,702). A més a més de ser el grup que mostra més sensibilitat en els indicadors que hem mesurat, també és el més sensible dins del propi col-lectiu de dones PDI. A mesura que augmenten l'edat i la categoria professional, el professorat, independentment del seu sexe, puntua menys en l'IGPS. És important destacar també de les dades obtingudes 
que, en tots els subgrups, la diferència entre dones i homes que se situen per sobre de la mitjana de tot el PDI és de més de 20 punts percentuals, tret del grup de catedràtics i catedràtiques, en què la diferència entre dones i homes és de 6 punts percentuals. Els contrastos més marcats es donen entre el grup de més de 40 anys (un 30\% més de dones que d'homes puntuen per sobre) i entre els de la categoria A (ajudants, becaris i associats, en el qual un 32\% més de dones que d'homes puntuen per sobre). Sembla, per tant, que les dones se situen per sobre de la mitjana en relació amb l'IGPG i són més sensibles en relació amb les mesures paritàries, els mecanismes formals d'igualtat i la sensibilitat de gènere, sobretot els col-lectius més joves de dones. Entre els homes, els joves estan més sensibilitzats. Per tant, la categoria docent i l'edat sembla que són factors que influeixen a tenir una percepció més o menys positiva sobre la necessitat d'establir mesures per la igualtat de gènere.

Respecte a la presència de gènere en les assignatures, l'enquesta mostra que el $10 \%$ dels homes del PDI afirma que la temàtica de gènere forma part del programa de l'assignatura que imparteixen, mentre que, en el cas de les dones, puja al 12,3\%. Els percentatges són similars davant l'afirmació sobre si es dedica temps en el transcurs de l'assignatura, tot i que no formi part explícita del programa. La divergència és més significativa quan la pregunta és si inclou la perspectiva de gènere en les assignatures de forma improvisada. En la resposta, hi trobem el doble de dones que afirma que ho fa (12,3\% de dones i 6\% d'homes). L'anàlisi dels plans d'estudi i de les guies docents on apareixen els programes de les assignatures confirma l'escassa presència de la temàtica de gènere als currículums de la Universitat.

La transversalitat de gènere no s'aconsegueix en els plans d'estudi analitzats — considerant que suposen un total de 173 assignatures. Són molt poques les assignatures $\mathrm{amb}$ algun contingut específic de gènere $\mathrm{o} a \mathrm{mb}$ temàtiques que hi estiguin relacionades.

Finalment, cal ressaltar la necessitat d'impulsar estudis que verifiquin les percepcions que homes i dones tenen de l'acadèmia. En aquesta direcció, i per posar de manifest només dues línies analítiques, d'una banda, caldria aprofundir en l'anàlisi dels factors organitzatius, formals i, sobretot, informals, que poden estar darrere de les diferències en les trajectòries professionals de les dones i els homes del PDI, i, d'una altra, cal també contrastar la hipòtesi que la vinculació més gran de les dones amb les tasques domèstiques i de reproducció tenen impacte sobre les seves carreres professionals i en quina mesura és així.

\section{Fonts bibliogràfiques}

Astelarra, Judit (2005). Veinte años de políticas de igualdad. Madrid: Cátedra.

BALBO, Laura (1978). La doppia presenza. Milà: Inchiesta.

Callejo Gallego, J. (2004). El techo de cristal en el sistema educativo español. Madrid: Universidad Nacional de Educación a Distancia.

Carrasquer, P.; Torns, T.; Tejero, E. y Romero, A. (1998). «El trabajo reproductivo». Papers, 55. 
CARreño, Antonieta. La carrera de les professores universitàries. Barcelona: Institut Català de la Dona. Universitat Autònoma de Barcelona.

Datos y cifras del sistema universitario, curso 2005/2006. Madrid: Consejo de Coordinación Universitaria, Ministerio de Educación y Ciencia, 2005.

EUROPEAN COMMISSION (2003). "Women and science». She figures, women and science, statistics and indicators. Science and Society, unitat 5. [http://europa. eu.int/comm/research/science-society/women-science/women-science_en.html]

GARCÍA DE LEÓN, Antonia (2001). Las académicas profesorado universitario y género. Madrid: Instituto de la Mujer.

García de Cortázar Nebreda, María Luisa (1997). Mujeres en minoría: Una investigación sociológica sobre las catedráticas de universidad en España. Madrid: Centro de Investigaciones Sociológicas.

Gensana Riera, M. Àngels (2005). Informes d'impacte de gènere. Barcelona: Institut Català de la Dona. Eines.

Gómez Bueno, C. (2001). "Mujeres y trabajo: Principales ejes de analisis». Papers, 63-64.

MARUANI, Margaret; ROGERAT, Chantal y TORNS, Teresa (2000). Las nuevas fronteras de la desigualdad entre hombres y mujeres en el mercado de trabajo. Barcelona: Icaria.

Política cientifica de la Unión Europea. Promover la excelencia mediante la integración de la igualdad entre géneros. Informe ETAN sobre les dones i la ciència. Brussel.les: Comissió Europea, 2001. [http://www.cordis.lu/rtd2002/science-society/women. htm]

SENSAT, N. y VARELla, R. (1998). «Las políticas dirigidas a las mujeres: la acción pública para la igualdad entre los sexos». A: Gomá, R. y Subirats, J. Políticas públicas en España: Contenidos, redes de actores y niveles de gobierno. Barcelona: Ariel.

2005 Pla d'Acció i Desenvolupament de les Politiques de Dones a Catalunya (2005-2007), aprovat per l'Acord de Govern de 22 de març de 2005.

2005 Informe de la Comissió al Consell, al Parlament Europeu, al Comitè Econòmic i Social Europeu $i$ al Comitè de les Regions sobre la Igualtat entre Dones i Homes. Brussel.les: Comissió Europea, 2006.

2005 Informe sobre la participación de las mujeres españolas en la toma de decisiones. Madrid: Asociación de Mujeres Juristas Themis, 2005.

IV Plan de Igualdad de Oportunidades entre Mujeres y Hombres. Madrid: Ministerio de Trabajo y Asuntos Sociales, 2000. 